\title{
RELACJA WSPÓŁWIĘŹNIÓW O OSTATNICH DNIACH ŻYCIA SŁUGI BOŻEGO KS. KONSTANTEGO BUDKIEWICZA
}

\section{(1867-1923)}

Wiosną 1923 r. opinię publiczną w kraju i zagranicą zbulwersował proces pokazowy duchowieństwa katolickiego wraz z arcybiskupem Janem Cieplakiem ${ }^{1}$ na czele. Proces ten miał miejsce w Moskwie w dniach 21-25 marca. W jego wyniku skazano na karę śmierci arcybiskupa oraz dziekana piotrogrodzkiego ks. Konstantego Budkiewicza, inni duchowni otrzymali łagodniejsze wyroki. Do Moskwy spływały noty protestacyjne m.in. z Polski, Niemiec, Francji, Stanów Zjednoczonych, Brazylii, Czechosłowacji, Hiszpanii, Anglii i innych krajów. Roman Knoll (1888-1946), chargé d'affairs Ambasady RP w Moskwie, zaproponował 30 marca wymianę więźniów, by ratować życie biskupa i ks. Budkiewicza. Rząd polski przekazał notę premiera Władysława Sikorskiego (1881-1943) przedstawicielowi Rosji Sowieckiej Leonidowi L. Obolenskiemu (1873-1930). Kardynał Aleksander Kakowski (1862-1938) przewodniczył 28 marca mszy w intencji ocalenia skazanych, a w całej Polsce odbyły się podobne nabożeństwa. W Warszawie zorganizowano wielotysięczną demonstrację przeciw decyzji sowieckiego trybunału. Ocalono tylko życie ks. arcybiskupa Jana Cieplaka, wyrok na ks. Budkiewiczu wykonano w nocy z Wielkiej Soboty na Niedzielę Zmartwychwstania (31 III 1923). Kapłan ten stał się jednym z symboli męczeństwa Kościoła w Rosji. Rok później w Polsce ukazało się tłumaczenie książki świadka moskiewskiego procesu duchowieństwa katolickiego, kapitana Francisa McCullagha - The bolshevik persecution of Christianity. Wstęp do polskiego tłumaczenia poetka Kazimiera Iłłakowiczówna kończy

Dr hab. IRENA WodZIANOwSKA - adiunkt Katedry Historii i Historiografii Europy Wschodniej, Instytut Historii na Wydziale Nauk Humanistycznych Katolickiego Uniwersytetu Lubelskiego Jana Pawła II; e-mail: irkawod@kul.lublin.pl

1 Jan CiePLAK (1857-1926) - absolwent Akademii Duchownej i jej wieloletni profesor, od $1908 \mathrm{r}$. biskup sufragan mohylewski, arcybiskup (1919). R. DzwOnkowski, Losy duchowieństwa katolickiego w ZSRR. 1917-1939. Martyrologium, Lublin 1998, s. 195-198; F. RuTKOwSKI, Arcybiskup Jan Cieplak (1857-1926). Szkic biograficzny, Warszawa 1934; I. WodzianowsKa, M.W. SzKarowskiJ, Jan Cieplak, http://www.polskipetersburg.pl/hasla/cieplak-jan [dostęp: 1.05.2019]. 
słowami: „Nie wolno zapomnieć krwi ks. Budkiewicza, nie wolno nam być obojętnymi na jęki prześladowanych braci w wierze"2.

Kim więc była osoba, której tak bardzo obawiał się rząd radziecki? Ksiądz Budkiewicz pochodził ze szlacheckiej rodziny z okolic Dyneburga, początkowe wykształcenie odebrał w domu, a następnie kształcił się w progimnazjum w Kielcach oraz gimnazjum w Lublinie ${ }^{3}$. W 1886 r. wstąpił do Seminarium Duchownego w Petersburgu, skąd jako zdolny alumn został skierowany na dalsze studia do Akademii Duchownej. Po trzech latach studiów (1893) uzyskał stopień kandydata teologii. Pracował kolejno jako wikariusz w Pskowie i Witebsku, jednocześnie ucząc religii w miejscowych szkołach. W grudniu 1903 r. został przeniesiony na podobne stanowiska do Petersburga. Od stycznia 1904 r. był wiceproboszczem, a od września 1905 do dnia aresztu w marcu 1923 r. proboszczem najstarszej i największej parafii Petersburga - św. Katarzyny. Tu też w pełni ujawniły się talenty administracyjne i organizatorskie ks. Budkiewicza. Do tej międzynarodowej parafii należeli wierni kilkunastu narodowości, głównie Polacy, Niemcy, Francuzi, Litwini, Łotysze i Białorusini. Od XVIII wieku głoszono tu kazania w języku polskim, francuskim, niemieckim i włoskim. Przy parafii działały szkoły oraz najważniejsze instytucje filantropijne, jak Rzymskokatolickie Towarzystwo Dobroczynności.

Ksiądz Budkiewicz w pierwszej kolejności zadbał o sprawy gospodarcze, budynek kościoła oraz szkolnictwo. Parafia posiadała nieruchomości, z których czerpała dochody na prowadzoną działalność edukacyjną i charytatywną. Kapłan przeprowadził inwentaryzację całego majątku kościelnego i razem z zarządem parafii wprowadził zmiany w jego zarządzaniu. Doprowadził do wzrostu dochodów parafii, zadbał o niezbędne remonty w kościele. Zwiększone dochody pozwoliły na podniesienie poziomu nauczania w obu szkołach średnich - progimnazjum męskim i żeńskim oraz na powołanie do życia szkoły zawodowej dla dziewcząt (1907). Ponadto otworzono pięć szkół elementarnych (1908) utrzymywanych przez admi-

${ }^{2}$ K. Illakowiczówna, Wstęp, [w:] F. McCullagh, Prześladowanie Chrześcijaństwa przez bolszewizm rosyjski, Kraków 1924, s. 8. K. Iłłakowiczówna (1888/1892-1983) poświęciła mu także poemat Opowieść o moskiewskim męczeństwie (1927) i wiersz Gtos księdza Budkiewicza zza grobu.

${ }^{3}$ B. Czaplicki napisał monografię pt. Ks. Konstanty Budkiewicz (1867-1923) - zycie i działalność, Katowice 2004. Powstały także biogramy: A. Petrani, Budkiewicz Konstanty, [w:] Encyklopedia Katolicka, t. II, Lublin 1976, kol. 1171; C. Falkowski, Budkiewicz Konstanty, [w:] Polski Stownik Biograficzny, t. III, Kraków 1937, s. 91-93; R. Dzwonkowski, Losy duchowieństwa katolickiego w ZSRR, s. 175-179; Т. ШишовА, Будкевич (Budkiewicz) Константин Ромуальд, [w:] Католическая Энциклопедия, Москва 2002, t. I, s. 776-777; С. Козлов, Прелат Константин Ромуальд Будкевич, [w:] Кровь мучеников есть семя Церкви, Москва 1999, s. 40-53; I. WodZIANOwSKa, M. SzKarowskiJ, Budkiewicz Konstanty, http://www.polskipetersburg.pl/hasla/budkiewicz-konstanty-romuald [dostęp: 7.05.2019]. 
nistrację kościoła. Nadzorował funkcjonowanie tych placówek oraz uczył w nich religii. W 1914 r. kształciło się w nich łącznie 1849 dzieci. Dbając także o duchową formację uczennic, zaprosił do współpracy św. Urszulę Ledóchowską (1865-1939), powierzając jej prowadzenie internatu dla dziewcząt. Powołał Stowarzyszenie Byłych Uczennic Pensji św. Katarzyny oraz zredagował statut Ogniska Młodych Polek. Działał także w Polskiej Macierzy Szkolnej, tworząc kółka samokształceniowe pod nazwą „ABC” dla najbiedniejszych mieszkańców stolicy.

Szczególną troską otaczał biednych i potrzebujących, angażując do pomocy parafian. Przez wiele lat był członkiem zarządu Rzymskokatolickiego Towarzystwa Dobroczynności przy parafii. Prowadził też nieodpłatne lekcje religii w sierocińcach na terenie miasta. Popierał rozwój prasy katolickiej, inicjując m.in. wydawanie tygodnika „Czytania Niedzielne” (1916-1918).

Dbał także o patriotyczne wychowanie młodzieży oraz podtrzymywał ducha polskiego w rosyjskiej stolicy. Za jego czasów kościół św. Katarzyny stał się „twierdzą" polskiego życia społecznego i kulturalnego nad Newą. Udostępniał budynki parafialne na organizowanie obchodów patriotycznych, spotkania organizacji i stowarzyszeń edukacyjnych oraz religijnych. W czasie I wojny światowej, gdy został powołany na wiceprezesa, a następnie prezesa Polskiego Towarzystwa Pomocy Ofiarom Wojny, parafia stała się piotrogrodzką centralą organizowania pomocy dla wysiedlonych Polaków na terenie całej Rosji. Dzięki jego życzliwości m.in. w 1917 r. odbywały się tu zajęcia Wyższych Kursów Polskich. Konsekwentny sprzeciw wobec rusyfikacji spowodował nieufność władz rządowych wobec jego osoby, co spowodowało kilkakrotne odrzucenie jego kandydatury na biskupa pomocniczego mohylewskiego (1914-1917). Z drugiej strony, angażował się w pomoc kapłanom wschodniego obrządku i Rosjanom katolikom. Udostępniał im kościół do odprawiania nabożeństw oraz plebanię, organizował kazania w języku rosyjskim.

Rozszerzył swoją działalność poza granicę miasta w 1908 r., gdy objął urząd dziekana dekanatu petersburskiego. Rozległy dekanat obejmował wówczas ponad 40 kościołów i kaplic na terenie guberni petersburskiej, pskowskiej, estońskiej, nowogrodzkiej oraz Finlandii. W ciągu kolejnych dwóch lat odbył co najmniej dziesięć wizytacji, poznając powierzony mu teren. Uczestniczył też w zakładaniu nowych parafii oraz w komitetach budowy kościołów.

W nowej sytuacji politycznej po rewolucji lutowej i abdykacji cara od marca 1917 do co najmniej kwietnia 1922 r. odbywały się w jego mieszkaniu spotkania duchowieństwa. On sam brał od 1917 r. aktywny udział w działalności wspomagającej polskich przesiedleńców i broniącej praw Polaków w Rosji Rady Społecznej przy kurii archidiecezjalnej, której pracami kierował w latach 1919-1920. Po dojściu do władzy bolszewików pozostał wraz ze swymi kapłanami i wiernymi, broniąc praw Kościoła do istnienia. Z inicjatywy ks. Budkiewicza, jak wspomina 
ks. Bronisław Ussas (1885-1977), powstał w 1918 r. Komitet Obywatelski, „, skład którego weszło 17 osób - przedstawiciele wszystkich warstw ludności polskiej w Piotrogrodzie. Była to wówczas jedyna organizacja społeczna polska, chociaż i nielegalna, która w latach 1918-1923 działała na terenie Piotrogrodu z wielkim pożytkiem dla kolonii polskiej. Ks. Prałat [Budkiewicz] był przez cały czas nie tylko prezesem, lecz prawdziwym «spiritus movens» Komitetu Obywatelskiego"4. W czerwcu 1918 r. został mianowany wikariuszem generalnym przy arcybiskupie Janie Cieplaku.

W tym trudnym okresie uwidacznia się przede wszystkim troska ks. Budkiewicza o kształcenie religijne oraz obrona praw Kościoła. Po zamknięciu szkół parafialnych zaczął organizować tajne kursy, które kapłani i nauczyciele prowadzili w mieszkaniach. Wystąpił też z inicjatywą stworzenia archidiecezjalnego Stowarzyszenia Rodziców i Wychowawców Katolickich, i mimo że nie uzyskał pozwolenia na jego funkcjonowanie, prowadził Stowarzyszenie nielegalnie. Troszczył się o zapewnienie dostępu katolikom w Piotrogrodzie i okolicach do sakramentów i Eucharystii, delegując kapłanów także poza obręb dekanatu. Po wyjeździe i aresztowaniach części duchowieństwa oraz zmniejszającej się liczby wiernych organizował na nowo życie wspólnot parafialnych. W jego mieszkaniu kilkakrotnie przeprowadzono rewizje. Zagrożony aresztowaniem, przez pewien czas ukrywał się w mieszkaniach parafian. Mimo to w tym okresie prowadził księgi parafialne, organizował cykle pogawędek religijnych, pisał okólniki do kapłanów i wiernych, instruując ich w sprawach przejęcia mienia kościelnego, utrzymania budynków kościelnych i innych. Organizował także pomoc dla aresztowanych księży oraz zajął się formacją kleryków. Od sierpnia 1922 r. wykładał w podziemnym seminarium duchownym.

Redagował i układał protesty wysyłane do IV Wydziału Komisariatu Sprawiedliwości, któremu podlegały sprawy religijnych wspólnot. Od 21 października $1921 \mathrm{r}$. przewodniczył także Komisji obrony i rewindykacji mienia kościelnego przy kurii arcybiskupiej. W 1922 r. Budkiewicz odmówił podpisania nieusankcjonowanej przez Watykan umowy z władzami o warunkach korzystania ze świątyń katolickich. W maju tego roku jako delegat arcybiskupa J. Cieplaka pertraktował z władzami w Moskwie w sprawach kościelnych, a w lipcu został jego pełnomocnikiem ds. uregulowania stosunku Kościoła katolickiego w Rosji do władz sowieckich. Na prośbę nuncjusza apostolskiego w Warszawie we wrześniu tegoż roku napisał raport (Status Ecclesiae in Russia) o stanie Kościoła katolickiego pod rządami bolszewików ${ }^{5}$.

${ }^{4}$ Biblioteka KUL [dalej: BU KUL], Oddział Zbiorów Specjalnych, Sekcja rękopisów, Zbiór B. Ussasa, rkps 787, k. 66.

${ }^{5}$ Zob. szerzej postawę i działalność ks. Budkiewicza w latach 1917-1923 [w:] B. CzAPLICKI, Ks. Konstanty Budkiewicz (1867-1923) - życie i działalność, Katowice 2004, s. 80-163. 
Po zamknięciu w grudniu 1922 r. kościoła św. Katarzyny gromadził wiernych na nabożeństwa w refektarzu i na korytarzach plebanii. Ksiądz Budkiewicz udał się ponownie do władz centralnych w Moskwie w listopadzie 1922 r. Stanął wówczas na czele delegacji parafian jako przedstawiciel arcybiskupa J. Cieplaka, wioząc ze sobą pisma arcybiskupa oraz pełnomocników parafian piotrogrodzkich z podpisami 2450 wiernych ${ }^{6}$ do Wszechrosyjskiego Centralnego Komitetu Wykonawczego. Pod koniec 1922 r., wobec zdecydowanej postawy parafian broniących praw Kościoła, był przesłuchiwany w sprawie piotrogrodzkiego duchowieństwa katolickiego, ponieważ oskarżano go o stworzenie antysowieckiej kontrrewolucyjnej organizacji. W oczekiwaniu na proces sądowy przebywał w areszcie domowym ${ }^{7}$. Ponownie odmówił wyjazdu z Piotrogrodu, uznał bowiem, że ratując siebie, zaszkodzi innym księżom. 2 marca 1923 r. mieszkanie Budkiewicza gruntownie przeszukano, a 3 marca otrzymał wezwanie do sądu w Moskwie. Nakaz stawiennictwa dostał także arcybiskup Cieplak oraz egzarcha rosyjsko-katolicki bł. Leonid Fiodorow ${ }^{8}$, a także dwunastu pracujących w Piotrogrodzie kapłanów. Wezwania do sądu oczekiwano już od co najmniej dwóch miesięcy. Po rekwizycji kosztowności kościelnych, odmowie podpisania umów na dzierżawę kościołów przez gromady świeckich katolików, a następnie obronie zamykanych świątyń, śledztw toczących się wobec duchownych, spodziewano się drastycznych rozwiązań. Polski minister spraw zagranicznych już 8 stycznia 1923 r. rozesłał do ambasad tajne pismo, w którym słusznie przewidywano, że sprawa sądowa arcybiskupa oraz „,wciągnięcie do niej wszystkich piotrogrodzkich księży ma stanowić, po zamknięciu 10 kościołów miejscowych, ostatni cios dla Kościoła w tej części Rosji”. Wobec tego uznano, że jedynym sposobem obrony jest informowanie rządów innych państw o sytuacji Kościoła i presja opinii publicznej.

Wezwani do Moskwy kapłani pośpiesznie załatwiali sprawy parafialne, zostawiając dyspozycje w razie swego aresztowania, odprawiali msze i głosili kazania w swych parafiach. Wieczorem 4 marca odjechali pociągiem do Moskwy żegnani

${ }^{6}$ Kopia pisma po rosyjsku: Instytut Polski i Muzeum im. gen. Sikorskiego w Londynie [dalej: IPMS], Ambasada R.P. w Londynie, sygn. A. 12 P 5/3, k. 15-16.

7 Archiwum Akt Nowych [dalej: AAN], Ambasada RP w Moskwie, sygn. 70, k. 41.

${ }^{8}$ Leonid Fiodorow (1879-1935) - studiował we Fryburgu Szwajcarskim, studyta, wybrany na pierwszym synodzie rosyjskiego Kościoła katolickiego wschodniego obrządku egzarchą katolików tego obrządku w Rosji. R. Dzwonkowski, Losy duchowieństwa katolickiego w ZSRR, s. 233-235.

${ }^{9}$ Cyt. za: IPMS, Ambasada R.P. w Londynie, sygn. A. 12 P.5/3, k. 9. Pismo rozesłano do polskich poselstw w Londynie, Paryżu, Berlinie, Hadze, Bernie, Kopenhadze, Madrycie, Pradze, Bukareszcie, Waszyngtonie, Rio, Tokio, Belgradzie, Konstantynopolu, Sztokholmie, Rydze, Helsingforsie. Odmienną pozycję zajęła Stolica Apostolska. Kardynał Gasparri, jak relacjonowała dyplomacja polska, wyraził przekonanie, że wszelkie „interwencje rządowe szkodzą nadając sprawie charakter polityczny" (telegram szyfrowy z 27 marca 1923). Tamże, k. 134. 
przez thumy wiernych. Plac przed dworcem kolejowym był wypełniony, a milicja musiała torować księżom drogę do pociągu. „Gdy z okna pociągu arcybiskup [Jan Cieplak] pobłogosławił lud, wszyscy zaczęli śpiewać Pod Twoją obronę"10.

W Moskwie grupą duchownych zaopiekował się dziekan moskiewski, ks. Piotr Zieliński ${ }^{11} .5$ marca zgłosili się wszyscy do sądu, otrzymując akta, na podstawie których mieli być osądzeni i skazani. Kapłani spotykali się na plebanii, dyskutowali nad linią obrony, odprawiali msze, zwiedzali miasto, czekając na wyznaczenie daty procesu. Panowało przekonanie, jak zaznacza ks. F. Rutkowski, że wyjaśnienie zarzutów przed Trybunałem w Moskwie pozwoli im na powrót do pracy duszpasterskiej ${ }^{12}$. Dobrej myśli był także ks. K. Budkiewicz, uznając, że najwyżej tylko część z nich zostanie wysłana z kraju Rad. Bardziej pesymistyczny był jednak arcybiskup Cieplak, który jeszcze w styczniu br. wyraził swe obawy pełnomocnikowi ds. repatriacji w Piotrogrodzie, spodziewając się wyroków kary śmierci ${ }^{13}$. Powiadomiono więc ponownie o oskarżeniach ambasadę polską.

10 marca przed południem na plebanię wkroczyła milicja. Wszyscy kapłani zostali aresztowani i przewiezieni najpierw do izolatora, a następnie do więzienia na Butyrkach. Areszt duchownych zbulwersował światową opinię publiczną. Interweniujący w ich sprawie kardynał Gasparri ${ }^{14}$ otrzymał ze strony przedstawiciela Sowietów Worowskiego zapewnienie, że życiu podsądnych nic nie zagraża ${ }^{15}$. Protesty wysłali zarówno przedstawiciele Kościołów chrześcijańskich, jak i politycy. 21 marca o godz. 12 rozpoczął się jednak w Moskwie proces pokazowy ${ }^{16}$. W trakcie kilkudniowego procesu obok duchownych, zeznawali także wezwani do Moskwy z Piotrogrodu świadkowie. Byli to szefowie działów cerkiewnych przy komitetach wykonawczych poszczególnych dzielnic Petersburga, którzy poświadczyli opór ka-

${ }^{10}$ B. SŁota, Życie i działalność o. Edwarda Juniewicza w latach 1918-1925, „Studia Redemptorystowskie" 2007, nr 5, s. 89.

${ }^{11}$ Piotr ZieliŃSKI (1863-1931) - absolwent Akademii Duchownej, duszpasterz w Mohylewie, Nieświeżu, Moskwie. R. Dzwonkowski, Losy duchowieństwa katolickiego w ZSRR, s. 529-530.

${ }_{12}$ F. Rutкowski, Arcybiskup Jan Cieplak (1857-1926). Szkic biograficzny, Warszawa 1934, s. 224.

${ }_{13}$ Por. odpis poufnego listu pełnomocnika Kotarskiego z dn. 17 stycznia 1923 do Departamentu Konsularnego MSZ w Warszawie. IPMS, Ambasada R.P. w Londynie, sygn. A. 12 P.5/3, k. 17.

${ }_{14}$ Pietro GASPARri (1852-1834) - kardynał, delegat Stolicy Apostolskiej w Ameryce Południowej, od 1904 r. sekretarz Komisji Kodyfikacyjnej, przygotowującej nowy kodeks prawa kanonicznego, od 1914 do 1930 r. - sekretarz stanu. Por. http:/www.catholic-hierarchy.org/bishop/bgaspp.html [dostęp: 28.08.2019].

${ }^{15}$ Por. kopia telegramu szyfrowego z dn. 17 marca 1923. IPMS, Ambasada R.P. w Londynie, sygn. A. 12 P.5/3, k. 132.

${ }^{16}$ Opis procesu: F. McCullagh, Prześladowanie Chrześcijaństwa przez bolszewizm rosyjski, s. 155-368; B. Czaplicki, Ks. Konstanty Budkiewicz, s. 164-195; F. RutKowsKi, Arcybiskup Jan Cieplak (1857-1926), s. 228-266. 
płanów wobec zorganizowania dzierżawy budynków kościelnych ${ }^{17}$. Po przemowie adwokatów i oskarżycieli ${ }^{18}, 25$ marca, po oddaniu głosu oskarżonym sąd po godz. 15 udał się na naradę. Po północy przewodniczący Najwyższego Trybunału Rewolucyjnego M.W. Gałkin ${ }^{19}$ i oskarżyciel N.W. Krylenko ${ }^{20}$ ogłosili wyrok ${ }^{21}$. Większość duchownych została oskarżona o ,sprzeciwianie się wycofaniu kosztowności, udział w organizacji, która przeciwdziała w celach kontrrewolucyjnych pracy organów sowieckich i o eksploatację w tych samych celach przesądów religijnych mas ludowych", zaś Franciszek Rutkowski ${ }^{22}$, Augustyn Pronckietis ${ }^{23}$ i 17-letni Jakub Szar-

${ }^{17}$ Byli to: Władimir Niemczenko s. Piotra, Grigorij Smirnow s. Piotra, Iwan Kiedik s. Sidora, Dmitrij Kolesnikow s. Stiepana i Wiera Rykunowa c. Iwana. IPMS, Ambasada R.P. w Londynie, sygn. A. 12 P.5/3, k. 165.

18 Przemówienia N.W. Krylenko [w:] Суд над католическими ксендзами (24 марта 1925), [w:] Н.В. Крыленко, Судебные речи. 1922-1930, Москва 1931, s. 3-34.

${ }_{19}$ Michaił Władimirowicz GaŁkIN (1885-1948) - urodzony w Petersburgu w rodzinie kapłana prawosławnego. Po rezygnacji ze studiów prawniczych wstąpił do seminarium ufijskiego, podejmując studium teologiczne. Wyświęcony w 1906 r., od 1908 wraz z ojcem zajął się publicystyką religijną. Od 1911 r. został także kapelanem armii rosyjskiej. Od 1917 r. współpracował z Leninem głównie na polu represji antyreligijnych. Od 1928 r. zatrudniony w Charkowie jako ateistyczny działacz partyjny. Lata II wojny światowej spędził w Nowosybirsku. Zob. M. KraPIVIN, Y. MaKarov, "Indispensable for the Work in Terms of the Decree of Separation of Church and State»: documentary portrait of M.V. Galkin (1885-1948), Bylye Gody, nr 34 (4) (2014), http://ejournal52.com/journals_n/1417271174.pdf [dostęp: 28.08.2019].

${ }^{20}$ Nikołaj Wasiljewicz KRYLENKo (1885-1938) - urodził się na Smoleńszczyźnie, w latach 18951903 pobierał nauki w klasycznym gimnazjum w Lublinie, gdzie świetnie opanował język polski. Do tej samej szkoły wcześniej uczęszczał ks. K. Budkiewicz. W 1903 r. rozpoczął studia na wydziale historyczno-filologicznym petersburskiego uniwersytetu. W czasie studiów był czynnym działaczem partyjnym, którym interesowała się policja. Po zakończeniu studiów (1909) ponownie wyjechał do Lublina jako nauczyciel historii i literatury. Został zmobilizowany w czasie I wojny światowej, pozostając nadal czynnym działaczem komunistycznym. W latach 1922-1931, będąc prokuratorem krajowym Rosyjskiej Federacji, występował jako główny oskarżyciel w najważniejszych procesach. Jego osobisty wróg Andriej Wyszynskij, prowadząc proces przeciw Bucharinowi, włączył także Krylenkę do tej sprawy. Proces zakończył się wyrokiem śmierci. Н.М. Якупов, Трагедия полководиев, Москва 1992, s. 41-65.

${ }^{21}$ Tekst wyroku m.in. [w:] BU KUL, Oddział Zbiorów Specjalnych, Sekcja rękopisów, Zbiór B. Ussasa, rkps 787, k. 298-301; kopia wyroku w języku rosyjskim i angielskim: IPMS, Ambasada R.P. w Londynie, sygn. A. 12 P.5/2, k. 40-48; A. 12 P.5/3, k. 127-129, 161-164, 166-175.

${ }^{22}$ Franciszek RutKowski (1883-1944) - absolwent Akademii Duchownej, kapelan arcybiskupa W. Kluczyńskiego (1911), proboszcz w Łudze. Po powrocie do kraju - sekretarz arcybiskupa A. Hlonda, dyrektor Biura Episkopatu Polski. R. Dzwonkowski, Losy duchowieństwa katolickiego w ZSRR, s. 417-418.

${ }^{23}$ Augustyn Pronckietis (1886-1970) - duszpasterz Połtawy, Krasławia, Dźwińska, od 1916 r. pracował w Piotrogrodzie. Po powrocie na Litwę pracował na terenie archidiecezji kowieńskiej. Tamże, s. 396-397. 
nas $^{24} \mathrm{z}$ kolei o „eksploatację przesądów religijnych mas i o opór władzy”. Arcybiskup Cieplak oraz ks. K. Budkiewicz, jako kierujący rzekomą kontrrewolucyjną organizacją księży, zostali skazani na rozstrzelanie, inni duchowni jako członkowie tejże organizacji otrzymali różne wyroki - od dziesięciu lat z surową izolacją (Stanisław Ejsmont $^{25}$, Edward Juniewicz ${ }^{26}$, Lucjan Chwiećko ${ }^{27}$, Paweł Chodniewicz ${ }^{28}$ i egzarcha L. Fiodorow) do trzech lat bez surowej izolacji (Antoni Malecki ${ }^{29}$, Antoni Wasilewski ${ }^{30}$, Piotr Janukowicz ${ }^{31}$, Dominik Iwanow ${ }^{32}$, Teofil Matulanis ${ }^{33}$, Jan Trojgo ${ }^{34}$,

${ }^{24}$ Jakub SZARNAS - pochodził z rodziny włościańskiej gub. kowieńskiej, student konserwatorium piotrogrodzkiego.

${ }^{25}$ Stanisław Eysmont (1887-1926) - absolwent Akademii Duchownej, wikariusz par. Trójcy Świętej w Mińsku, administrator par. św. Kazimierza w Piotrogrodzie (1918). Zmarł w Warszawie, wkrótce po powrocie do kraju. R. Dzwonkowski, Losy duchowieństwa katolickiego w ZSRR, s. 223-224.

${ }^{26}$ Edward JunIEwICz (1894-1989) - wikariusz przy kościele Nawiedzenia NMP w Piotrogrodzie. Po powrocie do kraju pracował na terenie diecezji wileńskiej i pińskiej. Następnie wstąpił do zakonu redemptorystów. Tamże, s. 272-273.

27 Lucjan Cнwiećко (1889-1944) - absolwent Akademii Duchownej, redaktor „Krynicy”, jeden z założycieli Chrześcijańskiego Zjednoczenia Demokratycznego (1917), profesor i ekonom seminarium duchownego, następnie administrator prokatedry w Piotrogrodzie. Po powrocie do Polski był rektorem Instytutu Misyjnego w Lublinie. Tamże, s. 194-195.

28 Paweł ChodniEwicz (1881-1949) - absolwent Akademii Duchownej, inspektor i katecheta gimnazjów przy kościele św. Katarzyny w Petersburgu, następnie inspektor seminarium duchownego oraz profesor dogmatyki w tajnym seminarium (1918-1923). R. Dzwonkowski, Losy duchowieństwa katolickiego w ZSRR, s. 191-192; M. W. SzKarowskiJ, Chodniewicz Pawet, http://www.polskipetersburg.pl/hasla/chodniewicz-pawel [dostęp: 1.05.2019].

${ }^{29}$ Antoni MALECKI (1861-1935) - działacz społeczny i religijny, organizator ochronki dla dzieci, zakładów rzemieślniczych i pierwszego gimnazjum polskiego. Wikariusz generalny archidiecezji mohylewskiej, w 1926 r. otrzymał sakrę biskupią. R. Dzwonkowski, Losy duchowieństwa katolickiego w ZSRR, s. 341-347.

30 Antoni WasILEwSKi (1869-1929) - absolwent Akademii Duchownej, wikariusz a następnie administrator parafii św. Piotra i Pawła w Moskwie, dziekan moskiewski, od 1910 r. rezydent w Petersburgu i kapelan ss. franciszkanek. Tamże, s. 499-501.

31 Piotr Janukowicz (1863-1937) - duszpasterz w m.in. Agłonie, Nowogrodzie, Kamieniu (k. Iwieńca), Penzie, Nieświeżu, od 1912 r. administrator parafii NMP i św. Franciszka w Petersburgu (1912), proboszcz w Leśnem (1922). Tamże, s. 261-263.

32 Dominik Iwanow-StoŁBIŃSKi (1883-po 1939) - duszpasterz w Rydze, Homlu, wicekanclerz kurii mohylewskiej i administrator parafii św. Stanisława w Piotrogrodzie. Tamże, s. 252-254.

33 Teofil Matulanis (Matulionis, 1873-1962) - duszpasterz parafii petersburskich, w 1929 r. potajemnie konsekrowany w Leningradzie. Od 1943 r. ordynariusz diecezji koszedarskiej, po zajęciu Litwy przez Armię Czerwoną ponownie uwięziony, wrócił do diecezji dopiero w 1956 r. Tamże, s. 351-353.

${ }^{34}$ Jan Trojgo (1880-1932) - absolwent Akademii Duchownej, profesor seminarium duchownego w Petersburgu (1910), kanclerz kurii metropolitalnej (1917). Tamże, s. 488-489. 
F. Rutkowski oraz A. Pronckietis). Jedyny świecki, oskarżany w tym procesie, Jakub Szarnas uznany został również winnym znieważenia władzy sowieckiej przy odbieraniu kosztowności w kościele Wniebowzięcia NMP, za co skazano go warunkowo na 6 miesięcy pozbawienia wolności, ostatecznie wypuszczono na wolność. Na ławie oskarżonych nie zasiadło ostatecznie jeszcze kilku duchownych objętych śledztwem - m.in. rektor seminarium duchownego ks. Ignacy Bałtruszys (zmarł) czy arcybiskup Edward Ropp, który opuścił kraj ${ }^{35}$.

Pokazowy proces arcybiskupa Cieplaka oraz 14 kapłanów katolickich odbił się głośnym echem na całym świecie. Władze radzieckie nie ugięły się jednak pod presją opinii międzynarodowej. Mimo zapewnień przedstawicieli rządu sowieckiego - Haneckiego w Moskwie i Oboleńskiego w Warszawie, że wyrok jest „tylko formalny i cała sprawa zostanie przeniesiona na drogę dyplomatyczną" ${ }^{36}$, zarządzeniem Prezydium Wszechrosyjskiego Centralnego Komitetu Wykonawczego z 30 marca 1923 r. wyrok uznano za prawomocny. Duchowni zostali po otrzymaniu wyroku rozdzieleni. Arcybiskup Cieplak przebywał w osobnej celi, odłączono także na kilka dni przed egzekucją ks. Budkiewicza. Przed północą 31 marca został on wyprowadzony ze swej pojedynczej celi i rozstrzelany w piwnicy więzienia ${ }^{37}$.

Polscy dyplomaci pracujący w Rosji opisali ks. Budkiewicza jako jednego z

najwybitniejszych i najbardziej zasłużonych księży w Rosji. Stojąc na czele największej parafji katolickiej w Rosji, która przez długie lata była katolickiem ogniskiem kultury i ducha życia polskiego, prałat Budkiewicz przetrwał czasy carskie i rewolucyjne i nie ustąpił z posterunku mimo najgorszych prześladowań bolszewickich, z niestrudzoną energią niosąc wiernym pomoc i opiekę religijną w najstraszniejszych chwilach. Taki jest pierwszy akt tej tragedji w Rosji, której na imię: walka z Duchem ${ }^{38}$.

${ }^{35}$ IPMS, Ambasada R.P. w Londynie, sygn. A. 12 P.5/3, k. 161.

${ }^{36}$ Cyt. za: tamże, k. 123.

${ }^{37}$ Istnieje również inna wersja miejsca śmierci ks. Budkiewicza, którą w korespondencji dyplomatycznej przekazano do Warszawy: „O szczegółach potwornego mordu nie ma bliższych szczegółów. Wiadomo tylko, że stracenie nastąpiło o godz. 4-tej zrana w piwnicach gmachu czerezwyczajki przy ulicy Łubianka. Księdza wprowadzono do piwnicy i tam jeden z czekistów strzelił mu w tył głowy. Ciało zostało wywiezione w niewiadomym kierunku. Istnieją przypuszczenia, że zwłoki zostały zakopane w miejscowości Sokolniki pod Moskwą wraz z ciałami 9 bandytów" (IPMS, Ambasada R.P. w Londynie, sygn. A. 12 P.5/2, k. 156). Z informacji otrzymanych przez sztab ze źródeł rosyjskich wynikało, że przy egzekucji ks. Budkiewicza byli obecni członkowie GPU Jewdokimow, Bergman i Krumm. W liście do obrońcy Bobriszczewa Bergman przedstawił, że ks. Budkiewicz przed śmiercią napisał list do papieża. „Budkiewicz był zupełnie spokojny i zwrócił się do Ewdokimowa temi słowami: „Proszę oddać moje ostatnie pozdrowienie ks. Cieplakowi i oświadczyć mu, że do ostatniej chwili pozostałem wierny Stolicy Apostolskiej”. Następnie komunista Złotkin „strzelił Butkiewiczowi w głowę", cyt. za: tamże, k. 158.

${ }^{38}$ Tamże, k. 156-157. 
Śmierć ks. Budkiewicza stała się symbolem nieludzkich rządów w Sowietach. W 1927 r. w Warszawie powstał Komitet ku Uczczeniu Pamięci Zamordowanego w Moskwie ś.p. Księdza Prał. Konstantego Budkiewicza, a w 1936 r. w kościele św. Anny wzniesiono jego pomnik ${ }^{39}$. Prezentowany czytelnikowi pełny tekst relacji o ostatnim miesiącu życia tego kapłana został spisany przez współwięźniów w lipcu 1923 r. Ich świadectwo, zapisane prawdopodobnie przez ks. Jana Trojgo, poświadczone zostało przez już aresztowanego, goszczącego ich w Moskwie dziekana Piotra Zielińskiego. Kapłani karę odsiadywali najpierw w więzieniu butyrskim, następnie skierowani zostali do domu poprawczego w Sokolnikach. Tu zostali rozdzieleni, gdyż grupa skazana na surową izolację została przeniesiona do lefortowskiego izolatora. Tylko arcybiskup Cieplak pozostawał najpierw w Butyrkach, a następnie na Łubiance. W Sokolnikach sygnatariusze protokołu sporządzili świadectwo o męczeńskiej śmierci ks. Budkiewicza ${ }^{40}$. Ponadto wszyscy, poza przebywającym w szpitalu ks. Ejsmontem, napisali swe życiorysy w okresie od 3 do 16 lipca $^{41}$. Prawdopodobnie przedstawicielom poselstwa polskiego zezwolono na kontakt ze skazanymi.

Cała dokumentacja - protokół oraz biografie duchownych, została przekazana drogą dyplomatyczną do Polski, a potem przez MSZ do prymasa Polski. Następnie materiały opatrzone komentarzami oraz innymi dokumentami, jak apel biskupów polskich do świata o zbrodniczym charakterze rządów rosyjskich z 1 maja $1923 \mathrm{r}$. (po francusku), podpisany przez metropolitę warszawskiego Aleksandra Kakowskiego (1862-1938) i prymasa Polski Edmunda Dalbora (1869-1926) ${ }^{42}$, rezolucja potępiająca mord na kapłanie przyjęta 12 kwietnia 1923 r. na posiedzeniu Sejmu $\mathrm{RP}^{43}$ - zostały przesłane do Stolicy Apostolskiej ${ }^{44}$. Odpis tekstu prawdopodobnie pozostał w Warszawie, a kopie rozesłano do placówek polskich na świecie ${ }^{45}$.

Po rozstrzelaniu ks. Budkiewicza rząd polski starał się o wymianę pozostałych więźniów (arcybiskupa Cieplaka, egzarchy Fiodorowa, Chodniewicza, Chwiećko, Ejsmonta, Iwanowa, Janukowicza, Juniewicza, Maleckiego, Matulanisa, Pronckietisa, Rutkowskiego, Trojgo, Wasilewskiego), jednak otrzymał odmowę. T. Mo-

${ }^{39}$ Wydrukowano także pocztówki, zob. https://polona.pl/item/ksiadz-pralat-konstanty-budkiewi cz,NzUyMjQ2NTY/1/\#info:metadata [dostęp: 5.08.2019].

${ }^{40}$ Opis warunków przetrzymywania kapłanów w Sokolnikach: AAN, Ambasada RP w Moskwie, s. 237-239.

${ }^{41}$ Zob. IPMS, Ambasada R.P. w Londynie, sygn. A.12 P.5/2, k. 167-180, 187-191.

${ }^{42}$ Archivio Segreto (Rzym) [dalej: AS], Arch. Nunz. Varsavia [dalej: ANV], vol. 225, f. 337-338v.

${ }^{43}$ Tamże, f. 335-336.

${ }^{44}$ Znajduje się obecnie [w:] AS, ANV, vol. 225, f. 332-338.

${ }^{45}$ Przechowuje je m.in. Polski Instytut Historyczny im. gen. Sikorskiego w Londynie: Ambasada R.P. w Londynie, sygn. A.12 P.5/2, k. 166-191. Kopia protokołu: tamże, k. 181-186. 
rawski, chargé d'affaires poselstwa polskiego, informował rząd również o odmowie arcybiskupa Cieplaka wniesienia jego imienia na listę wymiany personalnej ${ }^{46}$. Arcybiskupa ostatecznie wydalono z ZSRR w kwietniu $1924 \mathrm{r}$. W ramach wymiany znaleźli się rok później w kraju P. Chodniewicz, L. Chwiećko, E. Juniewicz oraz S. Ejsmont.

Pozostali kapłani po odbyciu kary powrócili do pracy duszpasterskiej. A. Malecki wraz A. Wasilewskim, J. Trojgo i D. Iwanowem wobec braków kapłanów powołali do życia w Leningradzie podziemne seminarium duchowne. Zostali ponownie aresztowani w styczniu 1927 r. i skazani. Po odbyciu wyroku ks. Iwanow wkrótce znowu został aresztowany i skazany na kolejne trzy lata łagrów. Ostatecznie w 1932 r. w ramach wymiany więźniów wrócił do Polski. W 1933 r., po kolejnym uwięzieniu, wrócili na Litwę także A. Pronckietis oraz konsekrowany wcześniej na biskupa Matulionis. W 1934 r. władze rosyjskie zgodziły się na powrót także konsekrowanego w Leningradzie biskupa A. Maleckiego. Schorowany i wycieńczony hierarcha, po kilku miesiącach zmarł w Warszawie.

Egzarcha Fiodorow ponownie został aresztowany w 1926 r. i skazany na trzy lata łagrów, a następnie zesłanie, gdzie zmarł. Na zesłaniu umarł również ks. Wasilewski, w szpitalu więziennym J. Trojgo. Do kraju nie wrócił też ks. Janukowicz, rozstrzelany 29 sierpnia 1937 na Białorusi. Dziekan moskiewski P. Zieliński, aresztowany w trakcie procesu, został zwolniony. Jednak już latem 1924 r. aresztowany ponownie i skazany na trzy lata zesłania na Ural. Odmówił w 1926 r. wyjazdu do Polski na drodze wymiany więźniów. Uwięziony po raz kolejny w 1930 r., zmarł rok później na zesłaniu.

W pamięci wiernych Leningradu pozostał ks. Paweł Chomicz, jedyny kapłan katolicki pracujący w czasie oblężenia miasta w okresie II wojny światowej. Po powrocie do miasta został ponownie aresztowany w 1927 r., a w trakcie odbywania kary w 1932 r. oskarżony o antyradziecką agitację wśród więźniów. Zwolniono go dopiero w 1936 r. z zakazem zamieszkania w dwunastu największych miastach ZSRR. Po kilkuletniej tułaczce w 1939 r. potajemnie wrócił do Leningradu. W lipcu 1941 r. został pełniącym obowiązki administratora apostolskiego Leningradu. Pozostawał z wiernymi w czasie wojny w mieście. Aresztowany w 1942 r., skazany na karę śmierci, rozstrzelany 10 września tegoż roku.

Wierność Kościołowi i męczeńska śmierć kapłanów pozostała w pamięci wiernych. W 1952 r. wszczęto proces beatyfikacyjny arcybiskupa Jana Cieplaka, w 2003 r. rozpoczął się proces beatyfikacyjny ks. Budkiewicza, P. Chomicza, A. Maleckiego, J. Trojgi. Pierwszy egzarcha Kościoła katolickiego obrządku bizantyjsko-rosyjskiego L. Fiodorow został ogłoszony przez Jana Pawła II błogosła-

${ }^{46}$ Kopia pisma T. Morawskiego. IPMS, Ambasada R.P. w Londynie, sygn. A. 12 P.5/3, k. 130. 
wionym 27 czerwca w 2001 r. we Lwowie. W 2017 r. w Wilnie odbyła się beatyfikacja sługi Bożego biskupa Teofila Matulanisa.

Męczenników w okresie dwudziestolecia międzywojennego upamiętnił po powrocie do kraju ks. Franciszek Rutkowski. W książkach poświęconych arcybiskupowi Cieplakowi i biskupowi Maleckiemu pozostawił także świadectwo męczeńskiej śmierci Konstantego Budkiewicza. Zacytował tam fragment prezentowanego protokołu, z niewielkimi zmianami stylistycznymi ${ }^{47}$. W całości zaś świadectwo to jest po raz pierwszy przedstawiane szerszemu gronu czytelników. Tekst publikowany jest z zachowaniem oryginalnej pisowni i interpunkcji.

Protokół, spisany przez księży: Chodkiewicza Pawła, Chwiećko Lucjana, Fiodorowa Leonidasa, Janukowicza Piotra, Juniewicza Edwarda, Iwanowa Dominika, Maleckiego Antoniego, Matulanisa Teofila, Pronckietisa Augustyna, Rutkowskiego Franciszka, Trojgo Jana i Wasilewskiego Antoniego - współpodsądnych i współwięźniów ś.p. ks. Prałata Konstantego Budkiewicza, dziekana piotrogrodzkiego i proboszcza parafii św. Katarzyny w Piotrogrodzie, o ostatnich dniach jego życia od soboty, dnia 3 marca, do Wielkiej Soboty, dnia 31 marca włącznie, $1923 \mathrm{r}^{48}$

W sobotę, dnia 3 marca 1923 r., około g. 2 po poł.[udniu], milicjant przyniósł do mieszkania ks. Budkiewicza w Piotrogrodzie piśmienne wezwanie dla niego i dla ks. Pawła Chodkiewicza, wikarjusza przy wzmiankowanym wyżej kościele św. Katarzyny, do natychmiastowego wyjazdu do Moskwy i stawienia się tam przed Najwyższym Trybunałem Sądowym ${ }^{49}$. Od chwili otrzymania wezwania do chwili odjazdu do Moskwy następnego dnia, tj. w niedzielę 4 marca, o g. 7 w.[ieczorem], ks. Budkiewicz, gotując się do podróży, załatwiał bieżące sprawy parafjalne z właściwym sobie spokojem, taktem i powagą. Tegoż dnia 3 marca, pod wieczór, odbył spowiedź. Nazajutrz, a była to 3-a niedziela Wielkiego Postu, ks. Budkiewicz odprawił w refektarzu plebanjalnym, gdzie była urządzona czasowa kaplica wskutek opieczętowania wszystkich kościołów w Piotrogrodzie przez miejscowe władze rządowe, cichą mszę św. o g. 10 r.[ano]. Po cichej mszy św., odprawionej tamże o g. 12 przez ks. Chodkiewicza, ks. Budkiewicz wygłosił kazanie, które było ostatniem jego kazaniem. Mówił na temat ewangielji tego dnia. W końcu kazania powiedział, że ks. Arcybiskup i prawie wszyscy księża piotrogrodzcy, w tej liczbie i on, zostali wezwani do Moskwy przed Najwyższy Trybunał Sądowy i że dzisiaj wieczorem wszyscy wezwani tam wyjeżdżają. Wyraził przytem nadzieję, uspokajając parafjan, że prawdopodobnie wkrótce wszyscy wrócą do Piotrogrodu, i zachęcił wiernych do modlitwy na intencję wezwanych przed sąd, a także zalecił wszystkim zachowanie spokoju i powagi, i zdanie się zupełne na Opatrzność Bożą. Z całego zachowania się, rozmów i wyraźnych słów ks. Budkiewicza było widać, że był on najmocniej prze-

\footnotetext{
${ }^{47}$ F. RutKowski, Arcybiskup Jan Cieplak, s. 283-284.

${ }^{48}$ AS, ANV, vol. 225, p. 332-334v.

49 Chodzi o Najwyższy Trybunał Rewolucyjny (Верховный Ревтрибунал), przed którym zostali postawieni duchowni.
} 
konany, iż bezstronne i spokojne wyjaśnienie sprawy [k. 332v] przed Najwyższym Trybunałem Sądowym w Moskwie wykaże, że w całej tej sprawie, od samego jej początku, duchowieństwu katolickiemu chodziło jedynie i wyłącznie o uzgodnienie kanonów prawa kościelnego i praw i rozporządzeń władzy świeckiej, i że w rezultacie dochodzenia sądowego Najwyższy Trybunał Sądowy uzna oskarżenia, skierowane przeciwko duchowieństwu piotrogrodzkiemu za bezpodstawne, a władza państwowa Rosyjskiej Respubliki znajdzie modus vivendi z Kościołem Katolickim w Rosji i wszyscy księża powrócą na swoje stanowiska. Prawda, ks. Budkiewicz nie wykluczał możliwości wysłania ks. Arcybiskupa i niektórych przynajmniej księży za granice Rosji i to uważał za maximum możliwej kary; nigdy jednak nie przypuszczał, by dochodzenie sądowe było prowadzone tak jawnie stronniczo i wykrętnie i by mógł zapaść tak niesłychanie ciężki i krzycząco niesprawiedliwy wyrok. Tegoż dnia 4 marca o g. 6 w.[ieczorem] ks. Budkiewicz wyszedł ze swego mieszkania, udając się na dworzec kolejowy. Na korytarzach plebanji, w podwórzu domu kościelnego i na ulicy licznie zebrani parafjanie i znajomi żegnali go ze łzami, całując go w ręce i prosząc o błogosławieństwo. Ponieważ trzeba było spieszyć się na pociąg, więc ks. Budkiewicz z ks. Chodkiewiczem pojechali razem sankami, które, przy wsiadaniu do nich księży, obstąpili parafjanie i jeszcze raz żegnali się serdecznie z odjeżdżającymi, okazując tem szczere przywiązanie do swych pasterzy. Ks. Budkiewicz spokojnie i łagodnie, prawdziwie po ojcowsku, do wszystkich przemawiał i wszystkich błogosławił. W drodze do dworca kolejowego powiedział ks. Chodkiewiczowi, że nie lubi takich pożegnań, które uważał za zbyt demonstracyjne, a które właściwie były tylko naturalnym wyrazem serdecznego przywiązania wiernych do swego pasterza i szczerego dlań współczucia. O g. 7 wiecz.[orem], przy wielotysięcznym napływie ludu wiernego na Placu Powstania (b. Placu Znamienskim), w gmachu dworca kolejowego i na peronie, ruszył pociąg, do którego z trudem przez te masy można się było przedostać, wiozący do Moskwy ks. Arcybiskupa Jana Cieplaka i 15 księży przed Najwyższy Trybunał Sądowy. W przedziale wagonu 3-ej klasy ks. Budkiewicz jechał razem z ks. Chodkiewiczem. W czasie podróży był małomówny i o sprawie nie wspominał. W Moskwie z dworca kolejowego udał się sankami razem z ks. Chodkiewiczem na plebanję przy kościele Śww. App. Piotra i Pawła ${ }^{50}$. W drodze, kiedy zaszła rozmowa o tem, że w Moskwie na dworcu kolejowym nikt nas nie spotkał, ks. Budkiewicz powiedział, że [k. 333] może to i lepiej, gdyż spotkanie mogłoby może rozjątrzyć władze rządowe i ujemnie wpłynąć na bieg sprawy. W ciągu kilkudniowego pobytu na plebanji ks. Budkiewicz mieszkał razem z adwokatem p. Kazimierzem Domaszewskim ${ }^{51}$, który

${ }^{50}$ Kościół pw. Apostołów Piotra i Pawła w Moskwie był pierwszą i najstarszą parafią w tym mieście. Znacjonalizowany w 1937 r., nadal nie został zwrócony wspólnocie katolickiej mimo wielokrotnych próśb.

${ }^{51} \mathrm{~W}$ sądzie zaś obrońcami duchownych byli W.M. Bobriszczew-Puszkin z Petersburga i N.W. Kommodow z Moskwy, profesjonalni adwokaci. Na swego obrońcę jeszcze w Petersburgu abp Cieplak wybrał Bobriszczewa, zaangażowanie którego opłaciła ambasada polska. AAN, Ambasada RP w Moskwie, k. 446-447. 
przyjechał z Piotrogrodu, i z nim omawiał sprawę obrony sądowej. Od dnia przyjazdu do Moskwy tj. od 5 marca do chwili aresztowania nas dnia 10 marca ks. Budkiewicz codziennie odprawiał mszę św. w kościele Śww. App. Piotra i Pawła. W ciągu tych dni, gdyśmy się wspólnie zbierali do stołu, był on zawsze spokojny, niekiedy nawet wesoły; zawsze jednak można było wyczuć, że myśli jego były skierowane ku sprawie sądowej, którą pragnął widzieć rozstrzygniętą w myśl Kościoła, choćby on sam czy kto inny z podsądnych osobiście ucierpiał. Sprawa Kościoła bezwarunkowo górowała w jego umyśle ponad wszystkiem. W sobotę, dnia 10 marca, około g. 6 po poł.[udniu], nastąpił nasz areszt. Ks. Budkiewicz zabrał z sobą, jak i wszyscy inni aresztowani, najkonieczniejsze rzeczy i spokojnie udał się pod eskortą do ciężarowego samochodu, oczekującego na ulicy przed kościołem, i stamtąd wszyscy obecni zostali zawiezieni do gmachu Najwyższego Trybunału Sądowego, gdzie przebyli niedzielę i poniedziałek do południa, kiedy to wszyscy podsądni, tj. 14 księży z ks. Arcybiskupem na czele i 1 świecki Jakób Szarnas, zostali przewiezieni do więzienia Butyrskiego, najsurowszego więzienia w Moskwie, i osadzeni na 13-ym korytarzu, w 56-ej kamerze ${ }^{52}$, wraz z innymi 9 więźniami świeckimi. W ciągu całego czasu, który upłynął od dnia aresztu do chwili wzięcia ks. Budkiewicza do pojedyńczej kamery tj. od 10 do 31 marca włącznie, był on, jak zwykle, spokojny, poważny i jakby więcej skupiony w sobie ${ }^{53}$. Codziennie odmawiał brewjarz, a w wolnym czasie czytał książki, gazety, gimnastykował się codziennie, nawet w dzień śmierci. Dnia 21 marca rozpoczął się sąd, który trwał do 25 marca włącznie. W jednym z tych dni ks. Budkiewicz spowiadał się przed jednym z kapłanów - współwięźniów. W czasie całego procesu sądowego zachowanie się ks. Budkiewicza było nacechowane spokojem, powagą i godnością prawdziwie chrześcijańską, szczególnie gdy się zważy nieustanne, wprost nieludzkie znęcanie się prokuratora sądu i nad jego osobą i jeszcze bardziej nad dogmatami i zasadami religji, przez podsądnych wyznawanej i bronionej. Każdy inny wobec takich napaści, mówiąc po ludzku, dałby wyraz mniej lub więcej ostry swemu oburzeniu na deptanie najświętszych wierzeń i uczuć religijnych; on bronił tego wszystkiego i odrzucał rzucone nań obelgi z dziwnym spokojem i iście chrześcijańską miłością nieprzyjaciół. I ten obowiązek miłości nieprzyjaciół, leżący na każdym chrześcijaninie, a tem bardziej, [k. 333v] na kapłanie, podkreślił ks. Budkiewicz w jednym ze swych przemówień i w ostatniej przemowie ${ }^{54}$. Na pytanie prokuratora Krylenki, jaki charakter miały narady u Arcybiskupa, ks. Budkiewicz spokojnie wyjaśnił, że dekret o rozdziale Kościoła i państwa wymagał wyjaśnienia wielu rzeczy z punktu widzenia prawa kanonicznego; nic przeto dziwnego, że księża w razach wątpliwych skierowywali się po wskazówki do swego Arcybiskupa; oskarżanie duchowieństwa piotrogrodzkiego o jakieś działania przeciwpaństwowe, o utworzenie jakiejś

52 Ros. - cela.

53 F. McCullagh opisał wygląd ks. Budkiewicza w trakcie procesu: „Ks. Budkiewicz wyglądał na człowieka, którego świat nie tylko nie rozpadł się w gruzy, ale nawet nie zadrżał w posadach" (Przésladowanie Chrześcijaństwa przez bolszewizm rosyjski, s. 167).

54 Relacja z mowy końcowej: tamże, s. 330-335; fragmenty innych przemówień na s. 262-272. 
organizacji o charakterze politycznym, jest faktycznie na niczem nie oparte, a samo prawo kanoniczne zabrania duchowieństwu brać udział w jakiejkolwiek akcji przeciwpaństwowej. On, jak i wszyscy jego towarzysze na ławie oskarżonych, bronili jedynie i wyłącznie spraw Kościoła i wiary. Zaznaczył także międzynarodowy charakter Kościoła Katolickiego, z czego naturalnie wynika dla katolików całego świata obowiązek uznania władzy i kompetencji Głowy tego Kościoła we wszystkich sprawach religijno-kościelnych, choć ten Najwyższy Zwierzchnik kościelny mieszka poza granicami tego czy innego państwa. Przy skrzyżowanych pytaniach prokuratora ks. Budkiewicz znużony, z natury flegmatyk, a przytem nie na tyle władający rosyjskim językiem, by natychmiast odparować z odpowiednimi odcieniami językowymi zarzuty oskarżyciela, zdawał się dawać czasami odpowiedzi, które na słuchaczach mogły zrobić wrażenie, że oskarżony jakby nie chce dać wyraźnej i jasnej odpowiedzi i jakby ucieka się do wykrętów. W ostatnie przemowie ks. Budkiewicz zupełnie jasno i wyraźnie zaznaczył swoje stanowisko w całej tej sprawie. Wskazał on mianowicie, że oskarżyciel w swych gwałtownych napaściach na podsądnych powoduje się głównie uczuciem nienawiści, zrozumiałej w działaczach rewolucyjnych, których psychologja oparta jest na uczuciu głębokiego oburzenia przeciwko swoim ciemiężcom, i że w nim samym nieraz uczucie oburzało się na niesprawiedliwość społeczną w Rosji. Rozumie on, dlaczego działacze rewolucyjni przypisują swym wrogom, za jakich uważają również podsądnych, uczucie nienawiści. Chociaż prokurator uśmiechał się ironicznie, słuchając słów ks. Budkiewicza, on z całym spokojem mówił dalej, że duchowieństwo katolickie nie zna, nie może znać i nosić w sercu nienawiści, ponieważ wychowane jest w duchu chrześcijańskiej miłości bliźniego, choćby ten bliźni był jego wrogiem i prześladowcą. Oskarżenie zarzuca księżom walkę polityczną z rządem. Walki żadnej nie było, była tylko samoobrona, była obrona praw Kościoła. Duchowieństwo nie ma prawa prowadzić walki politycznej. Kościół Katolicki stoi ponad partjami. Dla Kościoła obojętny jest ten czy inny ustrój państwowy, byle państwo szanowało prawa przyrodzone, boże i kościelne. Kościół odróżnia partję od państwa. Kościół nie może być obojętnym względem haseł, które występują przeciwko niechrześcijańskiej [k. 334] i podkopują wszelkie zasady społeczeństwa ludzkiego i ocenia komunizm wyłącznie z punktu widzenia religji. Pod tym względem oskarżeni bronili nie tyle siebie, ile swych przekonań religijnych. Księża nie mają również prawa prowadzić walki klasowej. Na wykrzyk oskarżyciela, czy ks. Budkiewicz miał głowę na karku, gdy jakoby czynił to, co mu oskarżenie zarzuca, on najspokojniej odpowiedział, że nie miałby istotnie głowy na karku, gdyby się porywał do politycznej walki z władzą Rad. Myślą przewodnią całej przemowy było to, że chciał on znaleźć wyjście z kolizji, jaka powstała między prawem kościelnem i wymaganiami władzy świeckiej. Wyrok śmierci ks. Budkiewicz przyjął spokojnie. Idąc za radą obrońców, podpisał przygotowaną tuż w sądzie prośbę o ułaskawienie od kary śmierci; podpisał ją, jak mówił potem sam, niechętnie i nie czytając jej nawet. -Te kilka dni, które upłynęly od 25 marca do jego wzięcia do osobnej kamery dnia 31 marca, przepędził tak, jak gdyby nic nadzwyczajnego w stosunku do jego osoby nie zaszło. W Wielki Piątek, dnia 30 marca, współwięźniowie przeczytali w gazecie o ułaskawieniu ks. Arcybiskupa i o pozostawieniu 
W mocy wyroku śmierci na ks. Budkiewicza. W tym czasie ks. Budkiewicza nie było w kamerze. Gdy wrócił do kamery, współwięźniowie na razie zamilczeli przed nim o nieułaskawieniu go; po pewnym jednak czasie powiedziano mu o tem i pokazano gazetę. Wówczas powiedział on spokojnie, że nie było potrzeby skrywać tego przed nim, bo na wszystko jest przygotowany ${ }^{55}$. Kiedy ks. prałat Malecki, z polecenia ks. Arcybiskupa, w prywatnej i poufnej rozmowie z ks. Budkiewiczem wspomniał mu o przygotowaniu się do możliwej śmierci, ks. Budkiewicz odrzekł, że jest zupełnie spokojny i na wszystko przygotowany, że mało kto go rozumie i że tylko Bóg jeden widzi jego ofiarę za wszystkie jego grzechy. W tych jego ostatnich, ze łzami wypowiedzianych słowach, czuć było szczere i całkowite zdanie się na wolę Bożą. W Wielką Sobotę, dnia 31 marca, około g. 10 r.[ano], wzięto go z naszej kamery do pojedynczej nr 42. Najspokojniej pożegnał się ze wszystkimi, prawdopodobnie przeczuwając, że więcej się z nami nie zobaczy. Tego samego dnia wieczorem ks. Budkiewicz odesłał nam książkę rosyjską, którą przy odejściu zabrał z sobą, i w niej zaznaczył, że jest sam jeden w kamerze nr 42, że jest tam czysto i ciepło. Kilku świeckich więźniów, którzy razem z nim siedzieli w kamerze i widzieli cały czas zachowanie się ks. Budkiewicza, a byli to rosjanie-schizmatycy ${ }^{56}$, z niezwykłem uznaniem i podziwem odzywali się o nim, o jego niezamąconym spokoju, i nazywali go szczęśliwym, bo cierpiał i umarł za dobrą sprawę ${ }^{57}$. Jeden z więźniów, mieszkających na tym samym korytarzu, co i ks. Budkiewicz, po wzięciu go od nas, mówił jednemu [k. 334v] z nas, że ks. Budkiewicz dnia 31 marca wieczorem był w kąpieli, pił herbatę, a około g. 11 1 12 w nocy przyszli dwaj ludzie i kazali mu zebrać rzeczy i zaprowadzili go do czekającego w podwórzu samochodu. Ks. Budkiewicz powiedział owym ludziom, że mu w nocy nie dają spokoju; sam był zupełnie spokojny, na pożegnanie na korytarzu poczęstował owego więźnia cygarami i udał się do samochodu. Według wiadomości, podanych w gazetach, został on stracony w nocy z dnia 31 marca na 1 kwietnia, a więc w nocy z Wielkiej Soboty na Wielką Niedzielę. ${ }^{58}$

Na zakończenie uważamy za potrzebne dodać, co następuje. Sąd, który miał miejsce w Moskwie w dniach 21-25 marca 1923 r. nad grupą księży katolickich a którego wyrokiem skazany został na śmierć i stracony ś.p. ks. prałat Konstanty Budkiewicz, był aktem czysto sekciarskiej zaciekłości i nienawiści do Chrystusa i Jego Kościoła i aktem zemsty względem tych, co nie bacząc na siłę fizyczną i zaciekłość wrogów,

55 Według o. E. Juniewicza powiedział: „Nic takiego, przeżyłem 55 lat, to wystarczy” (cyt. za: B. SŁota, Życie i działalność o. Edwarda Juniewicza, s. 109).

56 Prawosławni.

${ }^{57}$ O. Juniewicz we wspomnieniach dodaje: „Świeccy współwięźniowie podziwiali jego spokój i żegnali go z wielkim szacunkiem. Niektórzy całowali rękę, a po jego wyjściu mówili: «Oto prawdziwy bohater. Jeszcze nigdy nie widzieliśmy tak spokojnego, zrównoważonego skazańca na śmierć»" (cyt. za: B. SŁota, Życie i działalność o. Edwarda Juniewicza, s. 109).

${ }^{58}$ Ten fragment tekstu został przedrukowany przez ks. F. Rutkowskiego, z dodaniem zdania, którego w oryginale nie umieszczono: „Strzał do więźnia dano z tyłu, kiedy po schodach zstępował do podziemi na Łubiance" (F. RuTKowsKi, Arcybiskup Jan Cieplak, s. 284). 
chcieli pozostać wiernymi Chrystusowi i bronili praw Kościoła oraz dusz, ich pieczy powierzonych. Tak rozumieli ten sąd wszyscy oskarżeni i na równi z nimi zamordowany ś.p. ks. Budkiewicz. Nienawiść ta do Chrystusa i Jego Kościoła w szczególniejszy sposób przejawiła się w czasie sądu w bezecnych i bluźnierczych, a niczem nie krępowanych napaściach oskarżyciela, który nie krył się wcale ze swą nienawiścią do Kościoła Katolickiego.

Niniejszego protokołu nie podpisują osądzeni: ks. Arcybiskup Jan Cieplak, ponieważ siedzi osobno w innem więzieniu, mianowicie w Butyrskiem, i ks. Stanisław Eysymont, ponieważ niedawno zachorował umysłowo.

[własnoręczne podpisy] ks. Antoni Malecki prałat kap.[ituły] Archidiec[ezji] Mohyl[ewskiej]

Леонидъ Федоровъ Экзархъ русской-католической Церкви

Kanonik honorowy Archid[iecezji] Mohylowskiej ks. Antoni Wasilewski

Ks. Piotr Janukowicz, proboszcz kościoła św. Franciszka w Leśnem w Petrogrodzie

Ks. Edward Juniewicz, p.o. proboszcza kościoła św. Stanisława w Piotrogrodzie

Ksiądz Teofil Matulanis proboszcz kościoła Najświętszego Serca P. Jezusa w Piotrogrodzie

Ks. Lucjan Chwiećko, p.o. administratora kościoła Prokatedralnego

Ksiądz Augustyn Pronckietis wikaryusz Prokatedralny w Piotrogrodzie

Ks. Paweł Chodkiewicz, profesor Piotrogrodzkiego Seminarjum Duchownego

Ks. D. Iwanow, wice-kanclerz kuryi Metrop.[olitalnej] Mohyl.[ewskiej]

Ks. F. Rutkowski, kan.[onik] hon.[orowy] kap.[ituły] metrop.[olitalnej] mohyl.[ewskiej] rektor kaplicy za Moskiewską Rog.[atką ${ }^{59}$ i p.ob. proboszcza w Kolpinie

Kanclerz Kurji Metropolitalnej mohylewskiej ks. J. Trojgo

Ks. P. Zieliński, dziekan Moskiewski

Moskwa, Dom poprawczy w Sokolnikach

Dnia 16 lipca $1923 \mathrm{r}$.

\section{BIBLIOGRAFIA}

Archivio Segreto, Arch. Nunz. Varsavia, vol. 225.

Archiwum Akt Nowych, Ambasada RP w Moskwie, sygn. 70.

Biblioteka KUL, Oddział Zbiorów Specjalnych, Sekcja rękopisów, Zbiór B. Ussasa, rkps 781, 782, 787.

Instytut Polski i Muzeum im. gen. Sikorskiego w Londynie, Ambasada R.P. w Londynie, sygn. A.12 P.5/2, 15/3.

59 Kaplica za Moskiewską rogatką w Petersburgu powstała w miejsce niezrealizowanego projektu kościoła z początku XX wieku. W 1919 r. ostatecznie w mieszkaniu przy Międzynarodowym Prospekcie (Международный пр., 127) poświęcono kaplicę pw. NMP. Proboszczem został ks. Rutkowski, który po zamknięciu kaplicy w grudniu 1922 r. dojeżdżał także do Kołpino, Lubani i Ługi. 
Czaplicki B., Ks. Konstanty Budkiewicz (1867-1923) - życie i działalność, Katowice: Uniwersytet Śląski 2004.

Dzwonkowski R., Losy duchowieństwa katolickiego w ZSRR. 1917-1939. Martyrologium, Lublin: TN KUL 1998.

DzwONKowski R., Kościół katolicki w ZSRR. 1917-1939. Zarys historii, Lublin 1997.

Falkowski Cz., Budkiewicz Konstanty, [w:] Polski Słownik Biograficzny, t. III, Kraków 1937, s. 91-93.

McCullagh F., Prześladowanie Chrześcijaństwa przez bolszewizm rosyjski, Kraków 1924. Wymiana więźniów politycznych pomiędzy II Rzecząpospolitą a Sowietami w okresie międzywojennym. Dokumenty i materiały, oprac. W. Materski, Warszawa: ISP PAN 2000.

Petrani A., Budkiewicz Konstanty Romuald, [w:] Encyklopedia Katolicka, t. II, Lublin: TN KUL 1976, kol. 1171.

RutKowski F., Arcybiskup Jan Cieplak (1857-1926). Szkic biograficzny, Warszawa 1934.

RutKowski F., Biskup Antoni Malecki, Warszawa 1936.

SŁota B., Życie i działalność o. Edwarda Juniewicza w latach 1918-1925, „Studia Redemptorystowskie" 2007, nr 5, s. 78-118.

Ostrowski S., Ks. Konstanty Budkiewicz (1867-1923), [w:] Z murów św. Katarzyny. Księga pamiątkowa b. wychowanek i wychowanków gimnazjum przy kościele Świętej Katarzyny w Petersburgu, Warszawa 1933, s. 94-98.

Ostrowski S., Ś. P. Ksiądz Prałat Konstanty Budkiewicz na tle walki w obronie Kościoła Katolickiego i Wiary świętej, Warszawa 1929.

WodZIANOwsKa I., SzKarowsKiJ M., Budkiewicz Konstanty, http://www.polskipetersburg. pl/hasla/budkiewicz-konstanty-romuald

Шишова Т., Будкевич (Budkiewicz) Константин Ромуальд, [w:] Католическая Энциклопедия, t. I, Москва 2002, s. 776-777.

Козлов С., Прелат Константин Ромуальд Будкевич, [w:] Кровь мучеников есть семя Церкви, Москва 1999, s. 40-53.

ШКАРОВСКИй М.В., ЧЕРЕПЕНИНА Н.Ю., ШиКЕР А.К., Римско-Католическая Церковь на Северо-Западе России в 1917-1945 гг., Санкт-Петербург 1998.

\section{RELACJA WSPÓŁWIĘŹNIÓW O OSTATNICH DNIACH ŻYCIA SŁUGI BOŻEGO KS. KONSTANTEGO BUDKIEWICZA (1867-1923)}

\section{Streszczenie}

Rozstrzelanie w marcu 1923 r. ks. prałata Konstantego Budkiewicza, jak i proces pokazowy, który odbył się w Moskwie, zbulwersował opinię publiczną w Polsce i za granicą. W jego wyniku skazano na karę śmierci arcybiskupa Jana Cieplaka oraz dziekana piotrogrodzkiego, ks. Konstantego Budkiewicza, inni duchowni otrzymali łagodniejsze wyroki - od 3 do 10 lat więzienia. Noty protestacyjne wysłały rządy m.in. Polski, Niemiec, Francji, Stanów Zjednoczonych, Brazylii, Czechosłowacji, Hiszpanii, Anglii i innych krajów. Po rozstrzelaniu ks. Bud- 
kiewicza, w wyniku międzynarodowych protestów arcybiskupa wydalono z kraju. Trzynastu kapłanów po odbyciu kary wróciło do duszpasterskich obowiązków. Zagrożona ponownym aresztowaniem, część kapłanów w ramach wymiany więźniów do 1934 r. opuściła Związek Radziecki. Jako ostatni do Polski przyjechał bp Antoni Malecki, wycieńczony uwięzieniem i zesłaniem, kilka miesięcy po powrocie zmarł. Pozostali zginęli w łagrach lub zostali rozstrzelani w następnych latach.

Szerszemu gronu Czytelników prezentowane jest świadectwo o męczeńskiej śmierci ks. Budkiewicza spisane przez uwięzionych w 1923 r. kapłanów. Opisano w nim prawie miesiąc życia księdza przed wykonaniem wyroku śmierci. Ks. Budkiewicz przez prawie 20 lat był proboszczem największej parafii w Petersburgu pw. św. Katarzyny. Przy kościele działały szkoły podstawowe, dwa gimnazja, towarzystwo dobroczynne oraz bractwa modlitewne. Skupiało się tu także życie kulturalne i polonijne. Ks. Budkiewicz, od 1908 r. dziekan petersburski, opiekował się ponad 40 parafiami i kaplicami na rozległym terenie Pskowa, Nowogrodu oraz Finlandii. W 1918 r. został też wikarym generalnym bpa Cieplaka. Po dojściu do władzy bolszewików ks. Budkiewicz dzielnie bronił praw Kościoła. Zagrożony aresztowaniem, dwukrotnie odmówił wyjazdu do Polski. Za swój obowiązek uznał pozostanie z podległym mu duchowieństwem oraz wiernymi do końca. Spisany przez uwięzionych razem z nim kapłanów protokół został przekazany drogą dyplomatyczną do Polski, a następnie do Stolicy Apostolskiej. Stał się on świadectwem męczeństwa Kościoła katolickiego w Związku Radzieckim. Proces beatyfikacyjny ks. Budkiewicza rozpoczął się w 2003 r.

Słowa kluczowe: Konstanty Budkiewicz; abp Jan Cieplak; męczeństwo; proces pokazowy w Moskwie; Sankt Petersburg; Kościół katolicki w Rosji

\section{THE REPORT OF FELLOW PRISONERS ON THE LAST DAYS OF THE LIVE OF THE SERVANT OF GOD, FATHER KONSTANTY BUDKIEWICZ}

$$
\text { (1867-1923) }
$$

\section{Sum mary}

The execution of the prelate Konstantin Budkiewicz in March 1923, as well as an open court trial that took place in Moscow, shocked public opinion in Poland and abroad. Archbishop Jan Cieplak and the dean of Piotrogrod, Father Budkiewicz, were sentenced to death, while other clergy received less several sentences from 3 to 10 years in the Gulag. The governments of Poland, Germany, France, the United States, Brazil, Czechoslovakia, Spain, England and other countries sent protest notes. After was shot of Budkiewicz, as a resulr of international protest, the archbishop was expelled from the Soviet Union. 13 priests return to their pastoral duties in Piotrogrod after serving their punishment. Threatened with renewed arrest, part of the priests in the exchange of prisoners left the Soviet Union until 1934. Bishop Antoni Malecki was the last to come to Poland, exhauted by prisonment and exile, a few months after return he died in Warsaw. The others died in the Gulag after arrrested or were shot in the following years.

A testimony written down by priests imprisoned in 1923 about the martyrdom of Father Budkiewicz id present to a wider group of readers. It describes almost a whole month of his 
life before the execution od the death sentence. For almost 20 yers Fr. Budkiewicz was the parish priest of the largest parish in St. Catherine in St. Petersburg. Several primary schools, two middle schools, a charity society and fraternities operated at the parish. The cultural and Polnish community life was also concentrated here. Father Budkiewicz, since 1908 also was the Dean of St. Petersburg, took care of more than 40 parishes and chapels in the vast area of Pskov, Novgorod and Finland. In the 1918 he became prelate and Vicar General for Bishop Jan Cieplak, who served in Petersburg. After the Bolsheviks came to power, he bravely defended the rights of the Church and organised the clergy. From 1922 he was professor in the underground seminary. Threatened with arrest, he refused to go to Poland twice. He considered it his duty to remain in the clergy under his authority and to remain faithful to the end. The protocol written down by the priests imprisoned with him was transmitted through diplomatic channels to Poland and then to the Holy See. It became a testimony to the martyrdom of the Catholic Church in the Soviet Union. Father Budkiewicz's cause for sainthood was opened in 2003 and remains under investigation.

Key words: Konstanty Budkiewicz; Archbishop Jan Cieplak; martyrdom; an open court in Moscow; Saint Petersburg; Catholic Church in Russia 